\title{
Traveling Agents: Political Change and Bureaucratic Turnover in India
}

\section{Citation}

Iyer, Lakshmi, and Anandi Mani. 2012. “Traveling Agents: Political Change and Bureaucratic Turnover in India." Review of Economics and Statistics 94 (3) (August): 723-739. doi:10.1162/ rest_a_00183.

\section{Published Version}

doi:10.1162/REST_a_00183

\section{Permanent link}

http://nrs.harvard.edu/urn-3:HUL.InstRepos:33782993

\section{Terms of Use}

This article was downloaded from Harvard University's DASH repository, and is made available under the terms and conditions applicable to Other Posted Material, as set forth at http:// nrs.harvard.edu/urn-3:HUL.InstRepos:dash.current.terms-of-use\#LAA

\section{Share Your Story}

The Harvard community has made this article openly available.

Please share how this access benefits you. Submit a story.

\section{Accessibility}




\title{
TRAVELING AGENTS: POLITICAL CHANGE AND BUREAUCRATIC TURNOVER IN INDIA
}

\author{
Lakshmi Iyer and Anandi Mani*
}

\begin{abstract}
We develop a framework to empirically examine how politicians with electoral pressures control bureaucrats with career concerns and the consequent implications for bureaucrats' career investments. Unique microlevel data on Indian bureaucrats support our key predictions. Politicians use frequent reassignments (transfers) across posts of varying importance to control bureaucrats. High-skilled bureaucrats face less frequent political transfers and lower variability in the importance of their posts. We find evidence of two alternative paths to career success: officers of higher initial ability are more likely to invest in skill, but caste affinity to the politician's party base also helps secure important positions.
\end{abstract}

\section{Introduction}

In many countries, elected politicians and appointed bureaucrats are jointly responsible for governance. Bureaucrats typically face low-powered incentives, and politicians have limited constitutional power to hire or fire them. ${ }^{1}$ This is consistent with a desirable feature of the rule of law, which is that policy implementation not be politicized. Given such constitutional constraints, how can politicians facing electoral pressures ensure that their preferred policies are implemented by such protected bureaucrats? One approach may be to simply reserve the top bureaucratic posts for political appointees, as is the case in the U.S. federal government. Politicians can also use a variety of other devices. They may offer nonmonetary incentives, identify motivated agents who share their worldview, be gatekeepers with respect to who enters the bureaucracy, or be selective in the tasks they delegate to bureaucrats. ${ }^{2}$

In this paper, we examine a hitherto unexplored mechanism for the politician to retain control: being selective in which bureaucrat he or she delegates authority to, for various tasks. Our study makes theoretical and empirical contributions to the literature on bureaucratic delegation. Theoretically we endogenize bureaucrats' response to the

Received for publication November 3, 2009. Revision accepted for publication November 2, 2010.

* Iyer: Harvard Business School; Mani: University of Warwick.

We thank two anonymous referees, Andrew Foster, Karla Hoff, Sendhil Mullainathan, numerous seminar participants, and particularly Torsten Persson for extremely helpful comments. Filipa Jorge, Jetsada Chuenchoojit, and especially Maya Shivakumar provided excellent research assistance. We are extremely grateful to Siraj Hussain for his support and help with the data and also to Rahul Anand, Rajat Kumar, and several other officers of the Indian Administrative Service for many valuable insights.

A supplemental appendix is available online at http://www .mitpressjournals.org/doi/suppl/10.1162/REST_a_00183.

${ }^{1}$ Holmstrom and Milgrom (1991) and Dewatripont, Jewitt, and Tirole (1999) explore the normative rationale for providing low-powered incentives to bureaucrats, while Maskin and Tirole (2004) present the case for an independent bureaucracy insulated from political pressures.

2 All of these mechanisms have been explored in recent theoretical literature. See Prendergast (2007), Besley and Ghatak (2005), Mueller (2007), and Alesina and Tabellini (2007). Calvert and Weingast (1989) and Epstein and O'Halloran (1999) provide a related transactions cost approach to delegation of authority by politicians to bureaucrats. politician's delegation, given their career concerns. Empirically, we provide evidence on both the politician's and the bureaucrats' strategies, using a unique data set on the career histories of bureaucrats in the Indian Administrative Service. This is one of the very few detailed microempirical analyses of the interaction between politicians and bureaucrats.

Our work sheds light on the internal structure and working of government, which can greatly enhance our understanding of the policy process, a point Dixit (2010) emphasized. ${ }^{3}$ The explicit modeling of bureaucrat career concerns shows how the political process can affect the professionalization of the bureaucracy, defined in a Weberian sense. ${ }^{4}$ The degree of professionalization of the bureaucracy has been identified as a necessary condition for a state to be developmental and successfully achieve economic growth (Evans, 1995; Rauch \& Evans, 2000).

Our theoretical framework assumes that the politician principal cares about having control over bureaucrats' actions and has the power to assign specific bureaucrats to specific tasks, but lacks the power to recruit, dismiss, demote, or change the wages of appointed bureaucrats. Bureaucrats in turn care about the prestige and importance of the posts they are assigned to. The politician can therefore assign bureaucrats across posts of varying importance as a means to control them. In such a setting, will he or she reward Weberian bureaucrats with a reputation for expertise and independent judgment or just those who are loyal to his or her party? How will junior bureaucrats with career concerns respond to these incentives? Our theoretical framework examines these mechanisms and highlights two major sources of inefficiency. One stems from the fact that not all important posts are filled with the most skilled bureaucrats due to the politician's preference for a degree of control over bureaucrat outcomes. The other is that a politician's assignment practices result in underinvestment in skill by junior bureaucrats with career concerns, since investing in loyalty to specific politicians provides an alternative path to career success.

Our framework generates several testable hypotheses, which we test empirically using a unique data set on the career histories of 2,800 officers in the Indian Administrative Service (IAS) between 1980 and 2004. We combine these data

\footnotetext{
${ }^{3}$ Dixit (2010) likens the value added by such work to the progress made from research on the internal organization of firms: "This 'opening the black box of policy administration' is analogous to what occurred in the theory of the firm. Our view of the firm has changed for the better, from a mechanical maximizer of profit (or some other objective in cases of managerial or labor-managed firms) taking technology and factor prices as given, to an organization that must tackle manifold problems of internal governance and incentives. Analysis of the process of policy implementation promises similar progress."

${ }^{4}$ We refer to Weber's notion of a bureaucracy with meritocratic recruitment and security of tenure, where officers apply their technical expertise in the impartial execution of assigned tasks, to maximize efficiency.
} 
with data on political changes in major Indian states over the same period, proxy measures of bureaucrats' ability at the initial and later stages of their career, and a measure of the relative importance of different posts as viewed by bureaucrats themselves.

Our empirical findings on bureaucrat assignment patterns are highly consistent with the inefficiencies implied by our theoretical framework. First, we find that politicians do affect the process of bureaucrat assignment. A change in the identity of a state's chief minister (the de facto executive head of the state government) results in a significant increase in the probability of bureaucrat reassignments in that state. Second, we find that officers with higher initial ability face less frequent political transfers and lower variability in the importance of their posts. Third, over their career, we find that officers of high initial ability are no more likely to be assigned to important posts than other (loyal) officers. This confirms the model's view that there are alternative routes to success; it is not expertise alone that politicians value. Further support for this view comes from the finding that officers are more likely to be appointed to important positions when they belong to the same caste as the chief minister's party base. Fourth, consistent with the model's prediction that not all junior bureaucrats will invest in developing a reputation for expertise, we find that it is officers with high initial ability (that is, a comparative advantage in developing expertise) who spend significantly more time acquiring training during the course of their career. They are also more likely to be recommended for senior positions in the central government, suggesting that they have developed a greater reputation for expertise.

We extend our model to incorporate the role of subordinate or local politicians as an alternative channel through which politicians exert control over bureaucrats. This allows us to distinguish the role of political control from other motivations for bureaucrat transfers, such as increased efficiency through a better personal match between bureaucrats and politicians or experimentation to find the best match between bureaucrats and posts. Further, since bureaucrat assignments depend systematically on political considerations, outcomes may not differ systematically across districts with low and high transfer rates. Data on specific policy implementation outcomes such as road construction and immunization rates are consistent with this implication. ${ }^{5}$

Our work is related to the few systematic empirical analyses of the relationship between politicians and bureaucrats. Ramseyer and Rasmusen (2001) examine the impact of politically salient judicial decisions on the careers of judges in Japan, and Park and Somanathan (2004) document explicit links between Korean politicians and public prosecutors and their impact on bureaucrat assignments. The length of bureaucratic tenures has been shown to be an important determinant

\footnotetext{
5 See Bardhan and Mookherjee (2006) for a detailed model of the implications of delegating authority to bureaucrats versus local politicians in developing countries.
}

of long-term investments (Rauch, 1995) and the degree of professionalization of a bureaucracy (Evans, 1995). A larger empirical literature compares the policy decisions made by appointed versus elected public officials or the effects of rent-seeking opportunities, monetary incentives, and term limits for politicians. ${ }^{6}$ Previous empirical work on the Indian bureaucracy has been mostly descriptive (Wade, 1982; de Zwart, 1994; Potter, 1996; Das, 2001).

The rest of the paper is structured as follows. Section II describes the characteristics of the IAS and the political setting in India. Section III sets up our theoretical framework and derives testable hypotheses, which we take to the data. Section IV describes our data, and Section V tests the important hypotheses from our theory. Section VI extends our framework to include the role of subordinate (district-level) politicians, and Section VII concludes.

\section{Bureaucrats and Politicians in India}

\section{A. The Indian Administrative Service}

The IAS is the topmost layer of the government bureaucracy in India, consisting of fewer than 5,000 officers in 2005. It is the successor to the Indian Civil Service established by the British to administer India during the colonial period. IAS bureaucrats staff the most important positions in district administration, state and central government secretariats, and state-owned enterprises. A particularly important position is that of a district officer, who is responsible for ensuring law and order, providing certain judicial functions, organizing relief and rehabilitation in cases of natural disasters, implementing development policies, and overseeing all aspects of administration in a specific district. 7 These are positions of considerable importance: the median population of a district in 2001 was 1.5 million people, and district officers frequently administer budgets on the order of $\$ 2$ million. Lower levels of administration are staffed by members of state civil services.

IAS officers are career civil servants, and political neutrality is a requirement of their position. They cannot join political parties or be involved in any political events. Politicians are not involved in the hiring process of IAS officers. Recruitment is through either extremely competitive nationwide examinations conducted by an independent commission ("direct recruits"), or promotion of the best-performing officers from the lower state civil services (SCS promotees), the latter category being restricted to not more than one-third of officers in a state. ${ }^{8}$

\footnotetext{
${ }^{6}$ On comparing decisions of appointed versus elected officials, see Besley and Coate (2003), Besley and Payne (2003), Khemani (2003), Lim (2008), and Weingast and Moran (1983). Di Tella and Fisman (2004), Besley, Pande, and Rao (2007), Ferraz and Finan (2008), and Smart and Sturm (2008) analyze the incentives for elected officials.

7 These officers are variously known as district collectors, district magistrates, and deputy commissioners in different parts of India.

${ }^{8}$ Nearly $50 \%$ of all posts are reserved for members of historically disadvantaged sections of society.
} 
After recruitment and initial training, direct recruits are assigned to specific state cadres, where they typically spend most of their careers. This assignment of officers to states is done by a rigid (rather complicated) bureaucratic rule, resulting in a quasi-random assignment of officers to states. In particular, it is very difficult for elected politicians or the bureaucrats themselves to affect this assignment. A recruit can specify whether he or she wants to be assigned to his or her home state. Even if this person expresses the desire to go to his or her home state, it may not happen if (a) the state in question does not need any more officers, (b) if the previous officer assigned to the state was from that state (at most, onethird of the direct recruits assigned to a state can be natives of that state), (c) if the reservation criteria for the disadvantaged sections of society need to be satisfied, and (d) if too many top-ranked officers have already been assigned to that state. An officer who is not assigned to his or her home state is assigned to the next available state in alphabetical order. Since assignments proceed from the top-ranked recruit downward, these constraints are more likely to bind for lower-ranked recruits. Thus, all else being equal, higher-ranked candidates are more likely to be assigned to their home state. In our data, the correlation between the home state dummy and the dummy for an officer being ranked in the top $20 \%$ of his cohort is 0.28 , which is statistically significant at the $5 \%$ level.

The Constitution of India provides IAS officers considerable immunity from state-level politicians by stipulating that an IAS officer "holds office during the pleasure of the President" and cannot be "dismissed or removed by an authority subordinate to that by which he was appointed" (articles 310 and 311). This means that IAS officers cannot be dismissed or demoted by state-level elected representatives.

\section{B. Bureaucrat Careers}

IAS officers start by holding positions at the subdistrict level and move on to higher positions within the district, the state secretariat, or state-owned enterprises. Officers are usually appointed as district officers after attaining five to ten years of experience (this varies by state). Promotions are based on years of service for the first few years and have a merit-based component for the higher-level positions. IAS officers are evaluated by their superior officers in annual confidential reports. Wages and salaries are set by independent pay commissions and are determined by the bureaucrat's rank within the hierarchy.

IAS officers are subject to a comprehensive career review approximately twenty years after they join the service. This review is conducted by senior bureaucrats, who decide whether the officer is eligible to hold positions of joint secretary and higher in the central government at New Delhi; such positions are usually considered very prestigious. The selected officers are put on a panel from which they can be selected for such positions as and when the need arises in the central government. This process is called empanelment, and being empaneled is widely regarded as a signal of superior competence within the bureaucracy.

\section{India's Political System}

India is a parliamentary democracy in which elections are held every five years for both the central government in New Delhi and the 28 states that constitute the Indian Union. The head of the state executive is the governor, who acts on the advice of the chief minister and the council of ministers. The chief minister is usually the leader of the party that wins a majority of seats in the state legislature (similar to the prime minister at the national level). If the current chief minister loses the support of his or her party (due to internal party politics) or the parties in a coalition government fall apart, efforts are made to form another government, either by choosing a new leader from the same party or putting together another coalition. If these efforts fail, the central government often steps in to declare "president's rule" in the state: the administration of the state is brought under the central government until new elections are held. The election calendar resets to a five-year one after any such midterm poll. Differing incidence of midterm polls across states has now resulted in states' calendars being different from each other and from the national election calendar. For instance, the most recent national elections were in 2009 , but nine states had state elections in 2008.

\section{Transfers of IAS Bureaucrats}

IAS officers cannot be hired or fired by state-level politicians. However, they can be reassigned or transferred from one post to another. Such transfer orders are signed by the chief secretary (the top bureaucrat), who reports directly to the chief minister of the state. While bureaucrats can request specific assignments, they have very little power to affect the outcome of such requests. These transfers are almost always within the state or sometimes between the state and central governments; transfers across states are extremely rare.

In our data, we find that IAS bureaucrats are transferred quite frequently: over the period 1980 to 2004 , the probability that an officer experiences a transfer in a given year is $53 \%$ (see table 1). The average tenure of IAS officers in a given post is sixteen months, and only $56 \%$ of District Officers spend more than one year in their jobs. This is in violation of the recommendations, put forward by the Ministry of Personnel and the Fifth Pay Commission, for a three- to five-year tenure in each post. Figure 1 shows the transfer rates in major Indian States.

Interestingly, frequent transfer of bureaucrats has been a long-standing feature of the Indian bureaucracy. For instance, using data from the British colonial period, Potter (1996) finds that two-thirds of all district officers in 1936 had held their posts for less than one year. Gilmour (2005, p. 220) provides a vivid example from an even earlier period: "Between 1879 and 1885 Colonel Tweedie did three stints in Gwalior, 
TABLE 1.-Descriptive Statistics

Sample: Direct Recruits Who Joined the Service on or before 2000

\begin{tabular}{|c|c|c|c|c|c|}
\hline & Observations & Mean & s.d. & Minimum & Maximum \\
\hline \multicolumn{6}{|l|}{ Bureaucrat characteristics } \\
\hline Year of joining service & 2,802 & 1,984 & 8.11 & 1968 & 2000 \\
\hline Proportion female & 2,802 & 0.15 & 0.35 & 0 & 1 \\
\hline Proportion of home state officers & 2,796 & 0.33 & 0.47 & 0 & 1 \\
\hline Proportion in top 10 ranks of cohort & 2,797 & 0.12 & 0.32 & 0 & 1 \\
\hline Proportion in top 20 ranks of cohort & 2,797 & 0.23 & 0.42 & 0 & 1 \\
\hline Proportion in top 30 ranks of cohort & 2,797 & 0.34 & 0.47 & 0 & 1 \\
\hline Total weeks of training & 2,791 & 28.5 & 30.6 & 0 & 192 \\
\hline Weeks of foreign training & 2,788 & 15.9 & 23.6 & 0 & 172 \\
\hline $\begin{array}{l}\text { Proportion empaneled for central government posts } \\
\quad(1979-1987 \text { cohorts })\end{array}$ & 1,048 & 0.65 & 0.48 & 0 & 1 \\
\hline $\begin{array}{l}\text { Proportion same caste as chief minister's party base } \\
\quad \text { (Uttar Pradesh officers, 1990s) }\end{array}$ & 3,499 & 0.43 & 0.50 & 0 & 1 \\
\hline \multicolumn{6}{|l|}{ Bureaucrat transfers (1980-2004 annual data) } \\
\hline Transfer dummy & 54,798 & 0.53 & 0.50 & 0 & 1 \\
\hline Proportion in district officer posts & 54,798 & 0.07 & 0.26 & 0 & 1 \\
\hline Important post based on officer interviews & 54,798 & 0.51 & 0.50 & 0 & 1 \\
\hline Transfer to a post of similar importance & 54,248 & 0.31 & 0.46 & 0 & 1 \\
\hline Transfer to a post of different importance & 54,248 & 0.21 & 0.41 & 0 & 1 \\
\hline District officer transfer dummy (1985-2004) & 6,679 & 0.52 & 0.48 & 0 & 1 \\
\hline \multicolumn{6}{|l|}{ State-level political variables (1980-2004) } \\
\hline New chief minister (CM) dummy & 415 & 0.32 & 0.47 & 0 & 1 \\
\hline New party in power dummy & 415 & 0.17 & 0.37 & 0 & 1 \\
\hline State election year dummy & 415 & 0.23 & 0.42 & 0 & 1 \\
\hline General election year dummy & 415 & 0.32 & 0.47 & 0 & 1 \\
\hline
\end{tabular}

Figure 1.-Mean Transfer Rates in Major States, 1980-2004

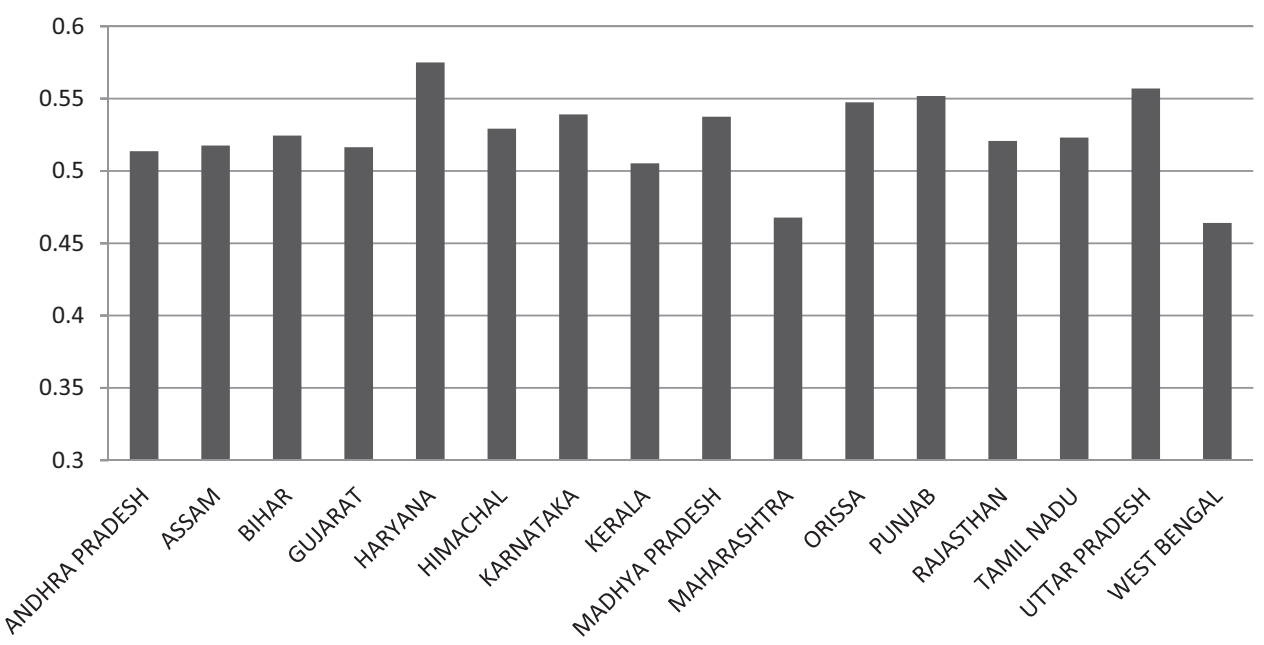

two in Baghdad, two in Ajmer, one in Jodhpur, one on the road between Peshawar and Kabul as Political Officer during the invasion of Afghanistan, and another as Political Officer in charge of Jalalabad."

Consistent with our hypothesis that such transfers are used as a control mechanism by politicians, we find that the average rate of bureaucrat transfers in a state increases significantly when there is a new chief minister in that state (see figure 2 for a graphic illustration of bureaucrat transfers in Tamil Nadu state). Such alleged politicization of the bureaucracy has become a major public policy issue in India. A public services bill currently in draft form proposes explicit limits on the political executive's ability to transfer bureaucrats before completing two years of service. ${ }^{9}$ However, politicians seem to value the ability to reassign bureaucrats frequently: during initial consultations regarding the bill, only eleven states agreed to have a minimum two-year tenure for district officers, and ten states refused outright.

\section{Theoretical Framework}

Our stylized framework captures how politicians facing short-term electoral pressures could use job assignments as a

${ }^{9}$ http://persmin.nic.in/EmployeesCorner/Acts_Rules/DraftPublicService Bill/PublicServiceBill_2007.pdf. 
Figure 2.-Chief Minister Changes in TAMil NADU

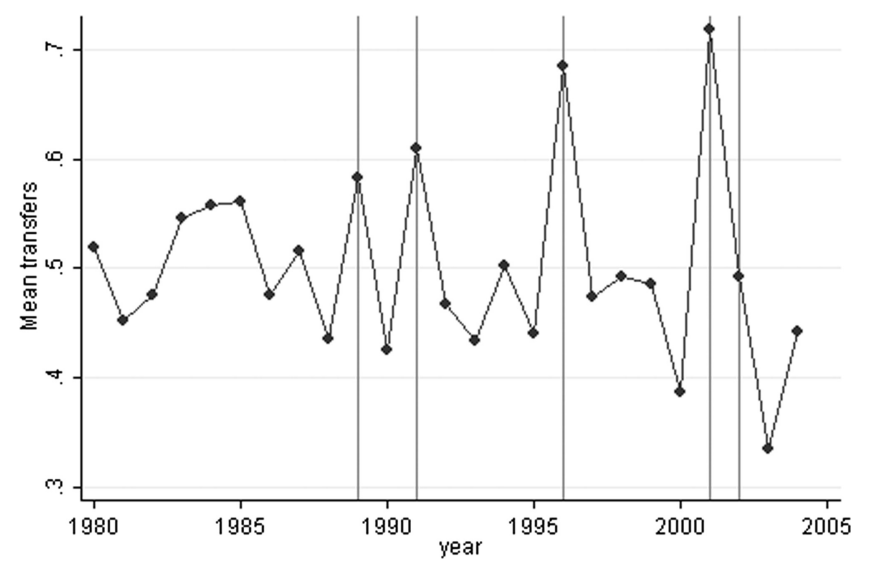

tool to control bureaucrats with long-term career concerns, as well as how bureaucrats' career investment decisions would respond to such incentives. We use this framework to derive testable hypotheses for our empirical work. In keeping with the Indian setting, we assume that politicians do not have access to the standard incentive mechanisms, such as hiring and firing officers or changing their wages. Our model has three key building blocks: (a) the politician seeks to control bureaucrats' output, (b) bureaucrats care about the prestige and importance of their jobs, and (c) junior bureaucrats can invest in either expertise or loyalty to a specific politician for career success. We lay out the basic features of our model here and refer readers to the online appendix for technical details.

\section{A. Bureaucrats}

A total of $B$ junior officers enter the bureaucracy with an ideological leaning, $j \in\{0,1\}$ and an initial ability $a_{i}$ that has a distribution $f(a)$. They can hold posts that are of two types: important or unimportant. Bureaucrats derive positive utility from holding important positions (because they provide opportunities to make influential policy decisions, for instance), but no utility from unimportant ones. Hence, officers define career success by the importance of their post assignments.

Given politicians' preferences, bureaucrats early in their career have two alternative routes to future success: invest in developing a reputation for skill or cultivate loyalty to the politician whose ideology they share. Developing expertise requires effort: officers can choose between high effort $e_{h}$ or low effort $e_{l}$. Greater effort increases their chances of becoming a type $H$ officer, but is more costly too in the sense of having a greater cost of effort. The effective cost of such effort is lower for those with higher initial ability, $c_{a}(e, a)<0$.

Denoting the lifetime expected utility of officers of types $H$ and $L$ by $U_{H}$ and $U_{L}$, respectively, a bureaucrat will choose high effort $e_{h}$ if and only if his or her expected utility net of the cost of effort is greater for high effort than for low effort: $e_{h} U_{H}+\left(1-e_{h}\right) U_{L}-c\left(e_{h}, a_{i}\right)>e_{l} U_{H}+\left(1-e_{l}\right) U_{L}-c\left(e_{l}, a_{i}\right) .^{10}$ Provided there are incremental rewards to developing expertise, it follows that officers with a high enough initial ability will invest effort in becoming high-skilled officers. Those with lower initial ability will prefer to cultivate loyalty to the politician whose ideology they share to further their career concerns. To simplify matters, we set $e_{h}=1$ and $e_{l}=0$, $c\left(e_{l}\right)=0$. In the above inequality, then, the bureaucrat chooses high effort in developing expertise if and only if

$$
\left(U_{H}-U_{L}\right)-c\left(1, a_{i}\right) \geq 0,
$$

and zero effort otherwise. Thus, starting with an initial ability $a_{i}$ and ideological leaning $j$, bureaucrats emerge as one of three types $b \in\left\{H, L_{0}, L_{1}\right\}$ : high skilled, loyal to party 0 , or loyal to party 1 .

Bureaucrats who do not invest in skill generate a low output $y_{L}$ in important posts regardless of party loyalty. High-skilled bureaucrats in important posts generate output $y_{H}$, which is at least as large as the output of loyal bureaucrats: $y_{H}=y_{L}+\theta$ where $\theta \sim U[0,1]$. We assume that the productivity advantage $\theta$ realized by a high-skilled officer does not depend on his or her initial ability $a_{i}$. In unimportant posts, we normalize output of all officers to 0 .

\section{B. Politicians}

As with bureaucrats, politicians are affiliated with one of two parties (ideologies), $j \in\{0,1\}$. The politician's ultimate goal is to have political power. ${ }^{11}$ Success in achieving this goal depends on how much of bureaucrats' public good output he or she can garner for constituents, as well as on overall public good efficiency.

Junior bureaucrats' career investments endogenously give rise to three types of bureaucrats. Unfortunately for politicians, bureaucrats of different types are not fully (or equally) amenable to their control; the share $s_{b}$ of a bureaucrat's output that politicians can control varies by type. Politicians have complete control over the output of officers loyal to their own party but little control over the output of officers loyal to the other party: $s_{L_{0}}=1$ and $s_{L_{1}}=0$ for a politician of type 0 and $s_{L_{0}}=0$ and $s_{L_{1}}=1$ for a politician of type 1 . In contrast to these extremes, a politician of either party has imperfect control over the output of a high-skilled officer: $s_{H} \in(0,1)$. This is because the policy decisions of high-skilled officers are ideologically neutral, coinciding with a politician's interests some of the time but not always. ${ }^{12}$ A typical example of this is a scenario where funds have been earmarked for the construction of, say, seven schools in a district. A bureaucrat

\footnotetext{
${ }^{10}$ In this expression, the probability of ending up as a type $H$ officer, for high- and low-effort levels, are assumed to be $e_{h}$ and $e_{l}$, respectively.

11 Given that nearly half of the cases of political turnover in our data occur in the absence of elections, we choose not to represent the politician's preferences in terms of utility from winning elections.

12 This is a "reduced-form" version of the preferences of bureaucrats and politicians modeled in Mueller (2007), where both parties' utilities depend on the efficiency and ideological match of policies chosen by the bureaucrat.
} 
who is loyal to the politician in power would agree to build all the schools in areas preferred by the latter, whereas one who is not loyal to this politician may disagree entirely on where the schools should be located in the district. A highskilled officer with a reputation for expertise would base his or her decision on a judgment of where the schools are most needed. As a result, he or she may end up allocating resources to some areas preferred by the politician but not all of them.

In addition, bureaucrats of different types differ in their productivity levels $y_{b}$. The politician has the authority to assign bureaucrats across $N$ posts, $N^{I}$ of which are important and $N^{U}$ of which are not. ${ }^{13}$ In order to maximize the size of bureaucrats' output under his or her control, he or she picks the number of important and unimportant posts $\left(n_{b}^{I}\right.$ and $n_{b}^{U}$ ) to award to each type $b$, mindful of his or her control over their output, $s_{b}$, but also their productivity level, $y_{b}$. We note that officer productivity here is assumed to be known to the politician; there is no asymmetric information. ${ }^{14}$ Hence, the politician's problem does not involve considerations of adverse selection or moral hazard. It is simply about how to make an assignment $\mathbf{n}_{\mathbf{b}}=\left\{n_{H}, n_{L_{0}}, n_{L_{1}}\right\}$ of the three types of bureaucrats across $N$ posts of varying importance given his or her own preferences.

In summary, the politician's preferences to maximize the size of bureaucratic output under his or her control can be formally represented as

$$
\begin{aligned}
\underset{\mathbf{n}_{\mathbf{b}}}{\operatorname{Max}} & \sum_{b} n_{b} \cdot s_{b} \cdot y_{b} \\
& \text { s.t. } \sum_{b} n_{b}^{I}+\sum_{b} n_{b}^{U}=N^{I}+N^{U}=N,
\end{aligned}
$$

where $s_{b}$ is the share of the total output $n_{b} y_{b}$ of type $b$ bureaucrats, under the politician's control. ${ }^{15}$

An alternative interpretation of the $s_{b}$ parameter could be the extent to which the bureaucrat transfers public funds to the politician for the latter's private gain (corruption). A loyal bureaucrat will transfer all public resources to his or her preferred politician, and while a high-skilled bureaucrat typically does not transfer all of the public funds to either type of politician. Note that when officers are highly skilled and loyal to politicians of both parties, this is simply a special case of a type $H$ officer with $s_{H}=1$ in our framework. We have chosen to assume $s_{H} \in(0,1)$ because it is more consistent with the basic transfer patterns observed in our data. As will become clear in our description of the equilibrium, if all officers chose to be of type $H$, there would be no reason for politically induced transfers.

\footnotetext{
${ }_{13}$ Important posts are scarce. Specifically, they are assumed to be fewer than the number of junior officers of either ideology entering the service.

14 This is a realistic assumption in our context, given that at most a few hundred officers officers serve at a time in each state, and each of them over several decades.

15 We refer readers to the online appendix for a few additional details about the politician's preferences.
}

\section{Timing}

Our model consists of three time periods. First is an incubation period: junior officers enter the bureaucracy, receive training, and make decisions on investments that influence their career prospects. In period 2, the bureaucrat's type is realized after these investments are made, and the politician currently in office makes an initial assignment of officers across posts of varying importance. In period 3, the incumbent faces a positive probability of losing power through elections or other means. If he or she manages to retain power, there is no change in bureaucrat assignments. If he or she loses power, the new politician who assumes office reassigns bureaucrats across posts so as to maximize gains to self (or his or her constituency of voters). Bureaucrats retire from the service at the end of period 3, and the game ends.

\section{Equilibrium}

An equilibrium in our framework consists of an initial ability threshold $a^{*}$ for bureaucrats and an assignment rule $\mathbf{n}_{b}^{*}$ for the politician such that both bureaucrats and politicians maximize their (expected) utility, and all available posts are filled. Proposition 1 describes the equilibrium in greater detail.

Proposition 1. Given a skill threshold $\widehat{\theta} \in(0,1]$ such that $s_{H} y_{H}(\widehat{\theta}) \geq y_{L}$ for a positive fraction of type $H$ officers, there exists an equilibrium $\left\{a^{*}, \mathbf{n}_{b}^{*}\right\}$ such that:

(i) All officers with initial ability at or above a certain threshold $a^{*}$ optimally choose the high effort level $e_{h}=1$ and those below $a^{*}$ optimally choose effort level $e_{l}=0$.

(ii) Politicians of party $j$ optimally assign important posts (in order of priority) to (a) high-skilled bureaucrats with realized skill levels $\theta \geq \widehat{\theta}$ and $(b)$ bureaucrats loyal to their own party but not to bureaucrats loyal to the other party- $n_{H}^{I}=(1-\widehat{\theta})\left(1-F\left(a^{*}\right)\right) B, n_{L_{j}}^{I}=$ $N^{I}-\left[(1-\widehat{\theta})\left(1-F\left(a^{*}\right)\right) B\right], n_{L_{j j}}^{I}=0$.

(iii) All the $N$ posts available are filled, $\sum_{b} n_{b}=N$.

Proof. See the online appendix.

Proposition 1 points out that officers with high initial ability are more likely to invest in skill. It also describes the assignment rule that politicians will use to maximize the size of bureaucrats' output under their control to increase their chances of staying in power. Regardless of their party affiliation, they will prefer to assign high-skilled officers to important posts over type $L$ officers as long as their output $s_{H} y_{H}>y_{L}$. Since $y_{H}=y_{L}+\theta$, bureaucrats with a high enough skill level will get priority in important posts regardless of the party in power, while the rest of such posts will be filled by officers loyal to that party. Loyalists of the other party get only unimportant posts. 
Given the optimal assignment rule $\mathbf{n}_{\mathbf{b}}^{*}$, reassignment of officers occurs (in period 3 ) only if the incumbent loses power to the other party. ${ }^{16}$ Specifically, a new politician in power will replace officers loyal to the other party who would have held several important posts in the previous period, with officers loyal to his or her own party. However, he or she is unlikely to transfer high-skilled officers out of important posts; after all, they would have been assigned to these posts only if they were highly productive relative to party loyalists $\left(s_{H} y_{H}>y_{L}\right)$. So, for instance, if a type 0 politician takes over from a type 1 politician who was originally in office, we can predict that:

(i) All type $L_{1}$ officers in important posts are transferred to unimportant posts.

(ii) They are replaced with type $L_{0}$ officers. Type $H$ officers who initially had important posts under politician from party 1 are retained by politician of party 0 .

These observations yield a few simple, testable hypotheses.

Hypothesis 1: Given bureaucrats who are loyal to either party ideology, political change induces bureaucrat transfers.

Hypothesis 2: Given any political change, high-skilled (type $H$ ) officers face fewer transfers than loyal officers (type $L_{0}$ and type $L_{1}$ ).

A high-skilled officer is better insulated from transfers following political change, so, unlike loyalist officers, he or she is less likely to be shunted in and out of important posts. Therefore, we posit that:

Hypothesis 3: Over the course of their career, the variation in the importance of the posts held by type $H$ officers is lower.

Of course, despite the fact that high-skilled officers are better insulated from the vagaries of political change, not all officers choose this route given the costs of such investment. As proposition 1 points out,

Hypothesis 4: Bureaucrats with high initial ability are more likely to invest in expertise and become type $H$ officers.

Given the politician's desire for control over bureaucrats' output, loyal officers are inefficiently favored over some high-skilled officers for important posts despite their lower productivity. The smaller the share $s_{H}$ of high-skilled officers' output that the politician can control, the fewer the number of important posts that will be assigned to them and the

\footnotetext{
16 Since output does not differ among posts at the same level of importance, transfers occur only across posts of differing importance. Transfer transaction costs (due to dislocation or inexperience of newly assigned officers on their jobs) would lower the incidence of transfers further.
}

larger the size of this inefficiency. This means that investing in skill does not necessarily guarantee greater career success to skilled officers over loyalists. In section V, we empirically examine the career success of bureaucrats following these two alternative paths, as well as the other hypotheses. Before we do so, we first describe the data gathered for this purpose.

\section{Data}

\section{A. Bureaucrat Transfers}

Our main data set contains detailed information on the career histories of all officers serving in the IAS as of October 2005, obtained from the Web site of the Ministry of Personnel, Public Grievances and Pensions. Our analysis focuses on 2,802 officers recruited directly (on the basis of a competitive examination) in nineteen major states in or before the year $2000 .{ }^{17}$ This is because we have information on both the initial examination rank and a long career path for these officers, which enables us to test key features of our model. Officers recruited after 2000 have not had time to invest in their careers and develop a reputation, and they have also experienced fewer instances of politician change. ${ }^{18}$ Fifteen percent of the officers in our data set are female, and 33 percent hold appointments in their home state, consistent with the official assignment rule described in section IIB (see table 1).

We have information on the start and end dates of each post held by the officer, the exact designation, the level of seniority, and the department. Seven percent of all posts are the particularly powerful district officer positions. Based on the start and end dates of each post, we construct a transfer dummy variable that equals 1 if an officer is recorded as starting a new post in a given year. If he or she does not start a new post in that year, the transfer dummy is 0. Multiple transfers within the same calendar year are coded as 1 as well, so that our measure is an underestimate of the actual transfer probability. We find that IAS officers experience very frequent transfers: the average transfer probability for an officer in a given year is $53 \% .19$

Since this data set consists of all currently serving officers, it excludes officers who retired in earlier years and is thus less comprehensive for the earliest cohorts. However, attrition due to nonretirement reasons is very small in our data. Based on administrative records, we find that about a quarter of officers recruited before 1979 are no longer present in

\footnotetext{
17 http://persmin.nic.in/ersheet/startqryers.asp, accessed OctoberDecember 2005. The states are Andhra Pradesh, Assam, Bihar, Chhattisgarh, Gujarat, Haryana, Himachal Pradesh, Jharkhand, Karnataka, Kerala, Madhya Pradesh, Maharashtra, Orissa, Punjab, Rajasthan, Tamil Nadu, Uttar Pradesh, Uttarakhand, and West Bengal, comprising $96 \%$ of India's population in 2001. Chhattisgarh, Jharkhand, and Uttarakhand were carved out of Madhya Pradesh, Bihar, and Uttar Pradesh, respectively, in November 2000. There were 4,047 officers serving in these states, of whom 2,802 were directly recruited on or before 2000 .

18 Forty percent of the officers recruited after 2000 have not experienced a single politician change, and less than $2 \%$ of their positions are important ones.

19 Eleven percent of the transfers in our data are caused by officers taking up more than one new job in a given year.
} 
our data, but only $4 \%$ of officers recruited between 1979 and 2000 are absent. We address the attrition issue in three ways. First, we include officer fixed effects in all of our specifications to control for factors such as the characteristics or size of specific cohorts. Second, all of our results are robust to excluding the cohorts prior to 1979. Third, we constructed a second position-level data set on district officers. In this specification, we have a panel data set for a set of specific positions over time, thereby alleviating concerns of selective attrition of officers from our data set. Transfer probabilities in our district officer data set are very similar to the overall data set-about $52 \%$ in a given year. ${ }^{20}$

\section{B. Importance of Posts}

Based on detailed interviews with several IAS officers, we constructed a measure of whether certain departments were considered more important, more prestigious, or more desirable than others by the bureaucrats themselves. ${ }^{21}$ We note that in our context, it is precisely such subjective measures of the importance of posts that are required. After all, it is only these perceptions of officers that allow politicians to use assignment across posts as carrots and sticks. While the constitution precludes formal demotion of IAS officers by state politicians, most officers would regard a move from the Department of Finance to, say, the Department of Youth Affairs as a de facto demotion.

We currently identify the following departments as important (out of a list of fifty departments): Excise and Sales Tax, Finance, Food and Civil Supplies, Health, Home, Industries, Irrigation, Public Works, and Urban Development. Departments were identified as desirable for several different reasons: the Home Ministry is considered important because it is a prominent position with responsibility for law and order, the Sales Tax department because it gives officers access to a lot of state funds, and Finance because this department controls the budgets of all other departments. ${ }^{22}$ We classify all district officer positions and central government positions as important. Overall, $51 \%$ of our observations involve officers holding important positions (table 1). Approximately threefifths of all transfers $(31 \%$ out of $53 \%$ ) take place between posts of similar importance; the rest involve a move from an important position to a nonimportant one, or vice versa.

\footnotetext{
20 We constructed the district officer data set by using the data on career histories from the first data set to identify district officer positions. We then filled in the gaps in these data by collecting information from the printed copies of the annually published IAS Civil List, which lists the position held by each officer at the beginning of the year.

${ }^{21}$ A department is coded as important if the majority of the officers who did the ranking regarded it as important.

22 These diverse considerations make it difficult to use more objective measures of importance, such as the share of that department in the state's budget. For instance, the Finance Department does not command a large share of the budget, while Education, which accounts for up to one-fifth of state expenditure, is not considered very prestigious by the bureaucrats themselves. This is probably because most of the budget is earmarked for teacher salaries, leaving very little room for bureaucratic discretion.
}

\section{Bureaucrat Ability and Loyalty}

We measure a bureaucrat's initial ability by the officer's rank within his or her cohort after initial recruitment and training. Using this, we created dummies for whether the officer was among the top ten, top twenty, and top thirty members of his or her cohort. We measure career investments in expertise by the total number of weeks spent in training and the number of weeks spent in foreign training; the latter requires more effort by the bureaucrat to secure funds and official leave, signaling a greater willingness to acquire competence. The ex post measure of expertise is a dummy for whether the officer has been empaneled, that is, reviewed and deemed eligible for senior central government positions in New Delhi. For the cohorts recruited between 1979 and 1987, approximately $65 \%$ of the officers are empaneled (table 1).

In order to examine the presence of a loyalty route to career success, we obtained data on caste identity for the officers of Uttar Pradesh and Uttarakhand cadres. Politics in the state of Uttar Pradesh were dominated by caste-based appeals by most parties in the 1990s (Chandra, 2004; Banerjee \& Pande, 2007). We compute a measure of whether the officer's caste is the same as that of the chief minister's party base. In terms of our framework, being of the same caste as that of the party base should make it easier for an officer to invest in loyalty to that politician. ${ }^{23}$

\section{Political Events}

We gathered data on changes in the identity of the chief minister in the nineteen major states over the period 1980 to 2004. ${ }^{24}$ We also collected information on the dates of state and national elections, as well as the party identity of the elected representative in each constituency, from the Web site of the Election Commission of India.

Over the years 1980 to 2004, states had an election about once every five years but a new chief minister once in three years (table 1). This is because a change in the chief minister of a state can happen in several ways. First, the incumbent party might lose a state election. Second, it might happen that the incumbent party is reelected but chooses a different leader to become the chief minister. Third, there can be a change in the chief minister even without elections, if his or her government loses a vote of confidence in the state legislature (see section IIC). Finally, in rare cases, there can be a change in the chief minister due to the death or resignation of the incumbent for reasons apart from losing legislative support. In our data, about $52 \%$ of new chief ministers come

\footnotetext{
${ }^{23}$ We obtained this information for $80 \%$ of the directly recruited officers in the states of Uttar Pradesh and Uttarakhand. We have currently assigned party-wise caste bases as follows: the Samajwadi Party is associated with appeals to Yadavs, Backward Castes, and Muslims; the Bahujan Samaj Party with the Scheduled Castes; and the Bharatiya Janata Party with the Forward Castes (Brahmins, Rajputs, Banias, and Kayasths).

24 This information is available from the official Web sites of the relevant state governments in most cases.
} 
TABle 2.-Political Change AND Bureaucrat Turnover

Dependent Variable: Bureaucrat Transfer Dummy

\begin{tabular}{|c|c|c|c|c|c|c|c|c|c|}
\hline & \multirow[b]{2}{*}{$\begin{array}{l}\text { New CM } \\
\text { (1) }\end{array}$} & \multirow[b]{2}{*}{$\begin{array}{l}\text { Control } \\
\text { for } \\
\text { Elections } \\
\quad(2)\end{array}$} & \multirow[b]{2}{*}{$\begin{array}{c}\text { Controls for } \\
\text { SDP and Crime } \\
\text { (1991-2003) } \\
\text { (3) }\end{array}$} & \multicolumn{2}{|c|}{$\begin{array}{c}\text { How CM Came to } \\
\text { Power }\end{array}$} & \multicolumn{2}{|c|}{$\begin{array}{l}\text { Transfers with and } \\
\text { without Promotion }\end{array}$} & \multicolumn{2}{|c|}{ Robustness Checks } \\
\hline & & & & $\begin{array}{l}\text { With party } \\
\text { Change } \\
\text { (4) }\end{array}$ & $\begin{array}{l}\text { With } \\
\text { Elections } \\
\quad(5)\end{array}$ & $\begin{array}{l}\text { Transfers } \\
\text { with } \\
\text { Promotion } \\
\text { (6) }\end{array}$ & $\begin{array}{l}\text { Lateral } \\
\text { Transfer } \\
\text { (7) }\end{array}$ & $\begin{array}{c}\text { Exclude } \\
\text { Cohorts prior to } \\
1979 \\
\text { (8) }\end{array}$ & $\begin{array}{l}\text { Include } \\
\text { Nondirect } \\
\text { recruits } \\
\text { (9) }\end{array}$ \\
\hline New chief minister dummy & $\begin{array}{l}0.051^{* * *} \\
(0.014)\end{array}$ & $\begin{array}{l}0.049^{* * *} \\
(0.015)\end{array}$ & $\begin{array}{l}0.046^{* *} \\
(0.017)\end{array}$ & & & $\begin{array}{c}0.004 \\
(0.005)\end{array}$ & $\begin{array}{l}0.046^{* * *} \\
(0.015)\end{array}$ & $\begin{array}{l}0.050^{* *} \\
(0.019)\end{array}$ & $\begin{array}{l}0.047^{* * *} \\
(0.014)\end{array}$ \\
\hline New CM, new party in power & & & & $\begin{array}{l}0.076^{* * *} \\
(0.022)\end{array}$ & & & & & \\
\hline New CM, no new party in power & & & & $\begin{array}{l}0.037^{* *} \\
(0.017)\end{array}$ & & & & & \\
\hline New CM after election & & & & & $\begin{array}{l}0.055^{\text {*** }} \\
(0.015)\end{array}$ & & & & \\
\hline New CM, no election & & & & & $\begin{array}{l}0.047^{* *} \\
(0.017)\end{array}$ & & & & \\
\hline State election dummy & & $\begin{array}{c}0.006 \\
(0.016)\end{array}$ & $\begin{array}{c}0.017 \\
(0.021)\end{array}$ & $\begin{array}{c}-0.012 \\
(0.017)\end{array}$ & $\begin{array}{c}0.002 \\
(0.013)\end{array}$ & $\begin{array}{c}0.008 \\
(0.005)\end{array}$ & $\begin{array}{c}-0.002 \\
(0.014)\end{array}$ & $\begin{array}{c}0.003 \\
(0.019)\end{array}$ & $\begin{array}{c}0.006 \\
(0.017)\end{array}$ \\
\hline General election dummy & & $\begin{array}{c}-0.024^{* *} \\
(0.011)\end{array}$ & $\begin{array}{c}0.014 \\
(0.020)\end{array}$ & $\begin{array}{c}-0.035^{* *} \\
(0.014)\end{array}$ & $\begin{array}{c}-0.024^{* *} \\
(0.011)\end{array}$ & $\begin{array}{c}-0.016^{* *} \\
(0.006)\end{array}$ & $\begin{array}{c}-0.007 \\
(0.007)\end{array}$ & $\begin{array}{c}-0.038^{* *} \\
(0.016)\end{array}$ & $\begin{array}{c}-0.021 \\
(0.013)\end{array}$ \\
\hline Years of experience & & $\begin{array}{l}0.191^{* * *} \\
(0.020)\end{array}$ & $\begin{array}{c}0.083 \\
(0.058)\end{array}$ & $\begin{array}{l}0.196^{* * *} \\
(0.019)\end{array}$ & $\begin{array}{l}0.191^{* * *} \\
(0.020)\end{array}$ & $\begin{array}{l}0.143^{* * *} \\
(0.010)\end{array}$ & $\begin{array}{l}0.035^{* *} \\
(0.015)\end{array}$ & $\begin{array}{l}0.673^{* * *} \\
(0.035)\end{array}$ & $\begin{array}{l}0.310^{* * *} \\
(0.016)\end{array}$ \\
\hline Years of experience (squared) & & $\begin{array}{c}-0.066^{* * *} \\
(0.005)\end{array}$ & $\begin{array}{c}-0.029^{* * *} \\
(0.010)\end{array}$ & $\begin{array}{c}-0.066^{* * *} \\
(0.005)\end{array}$ & $\begin{array}{c}-0.066^{* * *} \\
(0.005)\end{array}$ & $\begin{array}{c}-0.054^{* * *} \\
(0.003)\end{array}$ & $\begin{array}{c}-0.010^{* *} \\
(0.004)\end{array}$ & $\begin{array}{c}-0.215^{\text {*** }} \\
(0.012)\end{array}$ & $\begin{array}{c}-0.101^{* * *} \\
(0.005)\end{array}$ \\
\hline Officer fixed effects & Yes & Yes & Yes & Yes & Yes & Yes & Yes & Yes & Yes \\
\hline Year fixed effects & Yes & Yes & Yes & Yes & Yes & Yes & Yes & Yes & Yes \\
\hline Observations & 54,798 & 54,798 & 32,752 & 54,798 & 54,798 & 53,741 & 53,741 & 33,398 & 68,553 \\
\hline$R^{2}$ & 0.05 & 0.05 & 0.08 & 0.05 & 0.05 & 0.04 & 0.06 & 0.09 & 0.10 \\
\hline
\end{tabular}

to power as a result of a new party coming to power and only $54 \%$ as a result of elections.

\section{Politician Change and Bureaucrat Transfers}

\section{A. Are Bureaucrats Transferred When the Politician Changes?}

We quantify the relationship between political and bureaucratic turnover using the following linear regression specification:

$$
\text { Transfer }_{i j t}=a_{i}+b_{t}+c N e w C M_{j t}+X_{i j t}^{\prime} d+u_{i j t},
$$

where Transfer $_{i j t}$ is a dummy variable for whether officer $i$ of state $j$ was transferred in year $t, a_{i}$ is a fixed effect for the officer, $b_{t}$ is a fixed effect for the year, NewCM $M_{j t}$ is a dummy indicating whether a new chief minister came to power in state $j$ in year $t$, and $X_{i j t}$ is a vector of controls for other timevarying officer and state characteristics (years of experience, state and general elections). Since transfers within the same state might be correlated over time, we cluster our standard errors at the state level (Bertrand, Duflo, \& Mullainathan, 2004).

We find that despite the strong constitutional provisions for insulating the bureaucracy from politics, bureaucrat transfers significantly increase when a new chief minister (CM) takes office in the state (table 2, column 1). In terms of magnitude, this represents an increase of $10 \%$ over the baseline transfer probability of 0.53 . This result is robust to controlling for other time-varying state characteristics such as the timing of state-level and national elections (column 2), as well as controlling for real state domestic product, crime rates, and the incidence of riots (column 3). There could also be reverse causality in the sense that frequent transfers of bureaucrats might result in a deterioration of law and order or poor implementation of economic policies; hence, we present this specification only as a robustness check. ${ }^{25}$ Figure 3 shows that most of these transfers take place in the first four months after a new chief minister takes over rather than before the political change. Our results thus confirm hypothesis 1 .

In our theory, there is no distinction between party and politician. In practice, we expect that loyalty is partly to the party and partly to the politician, so there can be an effect from a change in the person in power, even if the party in power does not change, and the effect on bureaucrat reassignment should be larger if both the party and the politician change. We find that a chief minister who comes to power along with a new party is twice as likely to transfer bureaucrats than a chief minister who comes to power without a change in the party in power, an increase of $7.6 \%$ points in transfer probability compared to $3.7 \%$, although this difference is not statistically significant (table 2, column 4). In contrast, chief ministers who come to power as a result of elections are only slightly more likely to transfer bureaucrats compared to those who

\footnotetext{
25 Kingston (2004) examines the relationship between riots and transfer frequency in the 1980s and finds ambiguous results: transfers are negatively correlated with riots in the cross-section but positively related in the panel specification.
} 
Figure 3.-MONTHLY BUREAUCRAT TRANSFERS

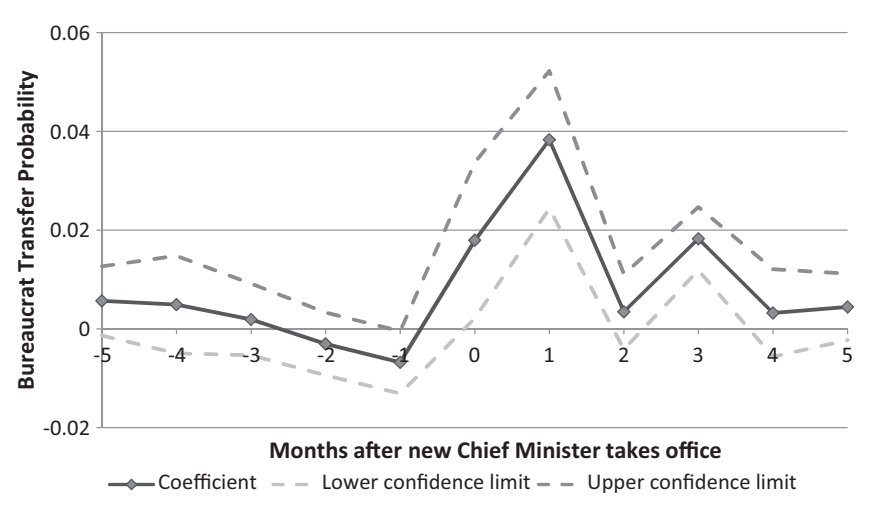

come to power in other circumstances (table 2, column 5). While the timing of elections is anticipated, nonelectionbased chief minister changes are unlikely to be so. Hence this last finding clarifies that the rise in transfers associated with political turnover is not driven by officer transfers bunched up around an expected chief minister change for pure administrative convenience. Further confirmation of this is provided by the fact that the majority of CM-induced transfers are lateral (not accompanied by a promotion), so that the reassignments we observe are not a reward for past performance or routine promotions that merely coincide with a new $\mathrm{CM}$ coming into office (columns 6 and 7). Finally, our results on the relationship between political change and bureaucratic turnover are not driven by selective attrition across cohorts or changes in hiring over time. The results remain essentially unchanged when we drop all cohorts prior to 1979 , where retirementrelated attrition is highest (column 8) or when we include officers who are hired through promotion from lower-level state civil services (column 9).

\section{B. Are High-Skilled Bureaucrats Less Likely to Be Transferred?}

We test hypothesis 2 by extending the regression equation (3) to include the interaction of political change and officer ability as follows:

$$
\begin{aligned}
\text { Transfer }_{i j t}= & a_{i}+b_{t}+c N e w C M_{j t}+\text { fNewCM }_{j t} \times \text { Ability }_{i} \\
& +X_{i j t}^{\prime} d+u_{i j t},
\end{aligned}
$$

where Ability $_{i}$ represents a measure of officer ability and $X_{i j t}$ is a vector of controls for other time-varying officer and state characteristics. Our measures of ability are based on the within-cohort ranks of the officers, as described in section IVC. We construct dummies for whether the officer was among the top ten, top twenty, or top thirty people in his or her cohort. Our theory predicts that the coefficient on NewCM $M_{j t} \times$ Ability will be negative. As in all the other regressions, standard errors are clustered at the level of the state.

As we explained in section IIA, higher-ranked officers are more likely to be assigned to their home states because of the characteristics of the assignment rule. Being assigned to their home state can have an independent effect on bureaucrats' propensity to invest in either ability or loyalty. Home state officers are familiar with the local language and culture, which might enable them to acquire expertise faster. They are also more likely to be familiar with local power and patronage networks, which might make it easier for them to develop loyalty links with state politicians. We therefore control for the effects of serving in home state in all our results.

Our officer-level regressions strongly support our hypothesis that high-skilled officers are significantly less likely to be reassigned when a new politician comes into office (table 3 , columns 1 and 2). In particular, an officer who was ranked among the top twenty in his or her cohort is 2.2 percentage points less likely to be transferred when a new politician takes office. Given that the average effect of an incoming politician is to increase transfer probability by 4.9 percentage points, this points to a $45 \%$ lower transfer probability for high-skilled officers. ${ }^{26}$

These results are robust to a variety of specification checks. First, we verify that the results on initial ability are not confounded with differences due to gender or differences over the career path of the bureaucrats. There is considerable evidence that women officers in the IAS suffer significant disadvantages in terms of career progression (Swarup \& Sinha, 1991). The relationship with politicians also might change over the course of an officer's career. We find that our results on initial ability are robust to controlling for the interaction of new $\mathrm{CM}$ with gender and experience (table 3, column 4). Another way to show this is to restrict our sample to male officers only. Our results on initial ability, in fact, become stronger when we restrict to this more homogeneous group of officers (table 3, column 5). Our results also retain their size and statistical significance when we control for potential sample selection by excluding cohorts prior to 1979 (column 6), use percentile ranks (ranked in the top 20\% of the cohort rather than the top twenty of the cohort) instead of the ranks themselves (column 7), and use a logit specification instead of a linear probability model (column 8 ). ${ }^{27}$

\section{Do Able Bureaucrats Have More Even Career Paths?}

We test hypothesis 3 by classifying our transfer dummy into two types: transfer between posts of similar importance (important-important or unimportant-unimportant) and

\footnotetext{
${ }^{26}$ We find similar results if we include all the officers (not just the direct recruits) and use the length of tenure in the previous post as a proxy for greater ability. Officers who have spent a longer time in their previous post are less likely to be transferred when a new chief minister takes office (results available on request).

27 We run the logit regressions without officer fixed effects, but with controls for the officer fixed characteristics such as ability, gender, and whether they serve in their home state. Note that all results remain robust if we use the full sample rather than male officers only. The coefficients are $-0.030,-0.024$, and -0.111 for the specifications in columns 6,7 , and 8 , respectively.
} 
TABle 3.-Are Able Officers Less Likely to Be Transferred by Politicians?

Dependent Variable $=1$ If Officer Was Transferred during the Year

\begin{tabular}{|c|c|c|c|c|c|c|c|c|}
\hline & \multicolumn{3}{|c|}{ Base Sample, OLS } & \multicolumn{5}{|c|}{ Robustness Checks } \\
\hline & (1) & (2) & (3) & $\begin{array}{l}\text { Controlling for } \\
\text { Gender and } \\
\text { Experience } \\
\text { (4) }\end{array}$ & $\begin{array}{l}\text { Restrict to } \\
\text { Male officers } \\
\text { Only } \\
\text { (5) }\end{array}$ & $\begin{array}{c}\text { Excluding } \\
\text { Cohorts Prior to } \\
1979 \text { (male } \\
\text { officers) } \\
\text { (6) }\end{array}$ & $\begin{array}{c}\text { Percentile } \\
\text { Ranks (male } \\
\text { officers) } \\
(7)\end{array}$ & $\begin{array}{c}\text { Logit } \\
\text { Specification } \\
\text { (male officers) } \\
\text { (8) }\end{array}$ \\
\hline New CM dummy & $\begin{array}{c}0.039^{* *} \\
(0.015)\end{array}$ & $\begin{array}{c}0.040^{* *} \\
(0.016)\end{array}$ & $\begin{array}{c}0.040^{* *} \\
(0.016)\end{array}$ & $\begin{array}{c}0.007 \\
(0.011)\end{array}$ & $\begin{array}{l}0.042^{\text {**** }} \\
(0.014)\end{array}$ & $\begin{array}{c}0.044^{* *} \\
(0.019)\end{array}$ & $\begin{array}{l}0.042^{\text {*** }} \\
(0.014)\end{array}$ & $\begin{array}{l}0.193^{* * *} \\
(0.067)\end{array}$ \\
\hline New $\mathrm{CM} \times$ top 10 Rank in Cohort & $\begin{array}{r}-0.025^{*} \\
(0.013)\end{array}$ & & & & & & & \\
\hline New $\mathrm{CM} \times$ top 20 Rank in Cohort & & $\begin{array}{c}-0.022^{* *} \\
(0.010)\end{array}$ & & $\begin{array}{c}-0.023^{* *} \\
(0.011)\end{array}$ & $\begin{array}{c}-0.037^{* *} \\
(0.013)\end{array}$ & $\begin{array}{c}-0.051^{* * *} \\
(0.014)\end{array}$ & $\begin{array}{c}-0.041^{* * *} \\
(0.013)\end{array}$ & $\begin{array}{c}-0.169^{* * *} \\
(0.055)\end{array}$ \\
\hline New $\mathrm{CM} \times$ top 30 Rank in Cohort & & & $\begin{array}{c}-0.011 \\
(0.009)\end{array}$ & & & & & \\
\hline New $\mathrm{CM} \times$ Home State & $\begin{array}{l}0.038^{\text {*** }} \\
(0.010)\end{array}$ & $\begin{array}{l}0.039^{* * *} \\
(0.011)\end{array}$ & $\begin{array}{l}0.037^{* * *} \\
(0.011)\end{array}$ & $\begin{array}{l}0.036^{* * *} \\
(0.011)\end{array}$ & $\begin{array}{l}0.049^{* * * *} \\
(0.013)\end{array}$ & $\begin{array}{c}0.053^{* * *} \\
(0.018)\end{array}$ & $\begin{array}{l}0.050^{* * *} \\
(0.012)\end{array}$ & $\begin{array}{l}0.188^{* * *} \\
(0.045)\end{array}$ \\
\hline New $\mathrm{CM} \times$ Female dummy & & & & $\begin{array}{r}-0.026^{*} \\
(0.013)\end{array}$ & & & & \\
\hline New $\mathrm{CM} \times$ Years of Experience & & & & $\begin{array}{l}0.030^{* * *} \\
(0.010)\end{array}$ & & & & \\
\hline Year fixed effects & Yes & Yes & Yes & Yes & Yes & Yes & Yes & Yes \\
\hline Officer fixed effects & Yes & Yes & Yes & Yes & Yes & Yes & Yes & \\
\hline Officer characteristics & & & & & & & & Yes \\
\hline Quadratic for years of experience & & & & Yes & & & & Yes \\
\hline Control for state and general elections & Yes & Yes & Yes & Yes & Yes & Yes & Yes & Yes \\
\hline Observations & 54,606 & 54,606 & 54,606 & 54,606 & 46,923 & 28,948 & 46,923 & 46,923 \\
\hline$R^{2}$ & 0.05 & 0.05 & 0.05 & 0.05 & 0.05 & 0.07 & 0.05 & \\
\hline
\end{tabular}

transfer between posts of dissimilar importance (importantunimportant or unimportant-important). We define importance as described in section IVB. We then run the following specification:

$$
\begin{array}{r}
\text { TransfertoDifferentImportance }_{i j t}=a_{i}+b_{t}+c N e w C M_{j t} \\
+ \text { fNewCM }_{j t} \times \text { Ability }_{i}+X_{i j t}^{\prime} d+u_{i j t}, \quad \text { (5) }
\end{array}
$$

where TransfertoDifferentImportance ${ }_{i j t}$ is a dummy variable that equals 1 if officer $i$ of state $j$ was transferred to a post of a different importance in year $t$ (transferred from an important post to an unimportant one or from an unimportant post to an important one), and all other variables are the same as in equation (4). Our theory predicts that the coefficient on NewCM $M_{j t} \times$ Ability will be negative.

We find clear support for the hypothesis that the highskilled types will have more even career paths. The coefficient on NewCM $M_{j t} \times$ Ability is negative and statistically significant when we measure initial ability by the officer being ranked in the top twenty of his or her cohort and by being ranked in the top thirty of that cohort (table 4, columns 2 and 3). We note that of the 2.2 percentage points lower transfer probability of officers in top twenty ranks (reported in table 3, column 2), 2 percentage points or over $80 \%$ are because they are less likely to be moved to posts of different importance. Qualitatively, this is consistent with our model, where the main reason for politically induced transfers is the movement of loyal, rather than able, officers from important to unimportant posts. As in table 3, we control for the effects of an officer being assigned to his or her home state to avoid any potential confounding effects of this variable with the initial ability ranking.

As in table 3, we perform a series of robustness checks for this result. The results remain unchanged when we control for interactions of political change with officer characteristics such as gender and years of experience (table 4, column 4), and become stronger when we restrict the sample to male officers only (table 4, column 5). The results remain robust when we further exclude cohorts prior to 1979 (column 6), use percentile ranks instead of just the ranks (column 7), and use a logit specification (column 8). ${ }^{28}$ Overall, we find confirmation for our hypothesis that the possibility of getting important positions is an important tool that politicians use to motivate bureaucrats in this setting.

\section{Bureaucrats' Career Concerns}

We first assess whether bureaucrats of higher initial ability invest more in developing expertise, a key assumption in our model. We use the extent of training undergone by the bureaucrat as a proxy for such investment in expertise, and run regressions of the form

$$
\text { Training }_{i c}=\alpha_{c}+\gamma \text { Ability }_{i c}+X_{i c}^{\prime} \delta+u_{i c},
$$

where Training ${ }_{i c}$ measures the weeks of training (domestic and foreign) undergone by officer $i$ of cohort $c, a_{c}$ is a fixed

\footnotetext{
28 As before, the results in columns 6 to 8 remain similar to the base specification of column 2 if we use the full sample rather than the sample of men only. The corresponding coefficients are $-0.018,-0.015$, and -0.119 respectively.
} 
TABle 4.-Do Able Bureaucrats HaVe Less VARIATION In Job QuAlity?

Dependent Variable $=$ Transfer to a Post of Different Importance

\begin{tabular}{|c|c|c|c|c|c|c|c|c|}
\hline & \multicolumn{3}{|c|}{ Base Sample, OLS } & \multicolumn{5}{|c|}{ Robustness Checks } \\
\hline & (1) & (2) & (3) & $\begin{array}{l}\text { Controlling for } \\
\text { Gender and } \\
\text { Experience } \\
\text { (4) }\end{array}$ & $\begin{array}{l}\text { Restrict to } \\
\text { Male } \\
\text { Officers } \\
\text { Only } \\
\text { (5) }\end{array}$ & $\begin{array}{l}\text { Excluding } \\
\text { Cohorts prior to } \\
1979 \text { (male } \\
\text { officers) } \\
(6)\end{array}$ & $\begin{array}{c}\text { Percentile } \\
\text { Ranks (male } \\
\text { officers) } \\
\text { (7) }\end{array}$ & $\begin{array}{c}\text { Logit } \\
\text { Specification } \\
\text { (male } \\
\text { officers) } \\
\text { (8) }\end{array}$ \\
\hline New CM dummy & $\begin{array}{c}0.016^{*} \\
(0.009)\end{array}$ & $\begin{array}{c}0.018^{*} \\
(0.009)\end{array}$ & $\begin{array}{c}0.019 * \\
(0.009)\end{array}$ & $\begin{array}{c}0.006 \\
(0.011)\end{array}$ & $\begin{array}{c}0.021^{* *} \\
(0.009)\end{array}$ & $\begin{array}{c}0.013 \\
(0.012)\end{array}$ & $\begin{array}{c}0.020^{* *} \\
(0.009)\end{array}$ & $\begin{array}{l}0.143^{* * *} \\
(0.052)\end{array}$ \\
\hline New $\mathrm{CM} \times$ top 10 Rank in Cohort & $\begin{array}{r}-0.011 \\
(0.010)\end{array}$ & & & & & & & \\
\hline New $\mathrm{CM} \times$ top 20 Rank in Cohort & & $\begin{array}{c}-0.020^{* *} \\
(0.008)\end{array}$ & & $\begin{array}{c}-0.019^{* *} \\
(0.008)\end{array}$ & $\begin{array}{c}-0.032^{* * *} \\
(0.009)\end{array}$ & $\begin{array}{c}-0.032^{* * *} \\
(0.010)\end{array}$ & $\begin{array}{c}-0.027^{* *} \\
(0.012)\end{array}$ & $\begin{array}{c}-0.187^{* * *} \\
(0.053)\end{array}$ \\
\hline New $\mathrm{CM} \times$ top 30 Rank in Cohort & & & $\begin{array}{r}-0.012^{*} \\
(0.007)\end{array}$ & & & & & \\
\hline New $\mathrm{CM} \times$ Home State & $\begin{array}{c}0.010 \\
(0.009)\end{array}$ & $\begin{array}{c}0.012 \\
(0.010)\end{array}$ & $\begin{array}{c}0.011 \\
(0.009)\end{array}$ & $\begin{array}{c}0.010 \\
(0.009)\end{array}$ & $\begin{array}{c}0.026^{* *} \\
(0.010)\end{array}$ & $\begin{array}{l}0.038^{* * *} \\
(0.012)\end{array}$ & $\begin{array}{c}0.025^{* *} \\
(0.011)\end{array}$ & $\begin{array}{l}0.145^{* * *} \\
(0.054)\end{array}$ \\
\hline New CM × Female Dummy & & & & $\begin{array}{r}-0.021^{*} \\
(0.011)\end{array}$ & & & & \\
\hline New $C M \times$ Years of Experience & & & & $\begin{array}{l}0.013^{* *} \\
(0.005)\end{array}$ & & & & \\
\hline Year fixed effects & Yes & Yes & Yes & Yes & Yes & Yes & Yes & Yes \\
\hline Officer fixed effects & Yes & Yes & Yes & Yes & Yes & Yes & Yes & \\
\hline Officer characteristics & & & & & & & & Yes \\
\hline Quadratic for years of experience & & & & Yes & & & & Yes \\
\hline Control for state and general elections & Yes & Yes & Yes & Yes & Yes & Yes & Yes & Yes \\
\hline Observations & 54,058 & 54,058 & 54,058 & 54,058 & 46,455 & 28,947 & 46,455 & 46,455 \\
\hline$R^{2}$ & 0.05 & 0.05 & 0.05 & 0.06 & 0.05 & 0.07 & 0.05 & \\
\hline
\end{tabular}

TABLE 5.-INITIAL ABILILTY AND INVESTMENTS IN EXPERTISE

\begin{tabular}{|c|c|c|c|c|c|c|}
\hline \multirow[t]{2}{*}{ Dependent Variable } & \multicolumn{3}{|c|}{ Total Weeks of Training } & \multicolumn{3}{|c|}{ Weeks of Foreign Training } \\
\hline & (1) & $(2)$ & (3) & (4) & $(5)$ & (6) \\
\hline Rank in top ten of the cohort & $\begin{array}{c}1.565 \\
(1.494)\end{array}$ & & & $\begin{array}{c}3.211^{\text {** }} \\
(1.198)\end{array}$ & & \\
\hline Rank in top twenty of cohort & & $\begin{array}{c}1.612 \\
(1.198)\end{array}$ & & & $\begin{array}{c}1.974^{*} \\
(1.042)\end{array}$ & \\
\hline Rank in top thirty of cohort & & & $\begin{array}{c}1.448 \\
(0.934)\end{array}$ & & & $\begin{array}{l}1.936^{* * *} \\
(0.623)\end{array}$ \\
\hline Female & $\begin{array}{c}1.237 \\
(1.462)\end{array}$ & $\begin{array}{c}1.240 \\
(1.465)\end{array}$ & $\begin{array}{c}1.214 \\
(1.457)\end{array}$ & $\begin{array}{c}1.662 \\
(1.164)\end{array}$ & $\begin{array}{c}1.669 \\
(1.182)\end{array}$ & $\begin{array}{c}1.632 \\
(1.175)\end{array}$ \\
\hline Home state dummy & $\begin{array}{r}-1.861^{*} \\
(1.043)\end{array}$ & $\begin{array}{r}-1.971^{*} \\
(1.077)\end{array}$ & $\begin{array}{r}-1.946^{*} \\
(1.075)\end{array}$ & $\begin{array}{c}-0.524 \\
(1.036)\end{array}$ & $\begin{array}{r}-0.449 \\
(1.027)\end{array}$ & $\begin{array}{r}-0.457 \\
(1.001)\end{array}$ \\
\hline Year of recruitment fixed effects & Yes & Yes & Yes & Yes & Yes & Yes \\
\hline Observations & 2,780 & 2,780 & 2,780 & 2,777 & 2,777 & 2,777 \\
\hline$R^{2}$ & 0.37 & 0.37 & 0.37 & 0.24 & 0.24 & 0.24 \\
\hline
\end{tabular}

Robust standard errors in parentheses. Significant at $* 10 \%, * * 5 \%, * * * 1 \%$. Base sample: Direct recruits who joined the service on or before 2000.

effect for the cohort (so that we are comparing each officer only to others of his cohort), Ability $_{i c}$ is the initial withincohort rank of officer $i$, and $X_{i c}$ represent other characteristics of the officer. In our model, we expect the coefficient on Ability to be positive because of able officers' comparative advantage in developing expertise.

We find that bureaucrats of higher initial ability undergo longer training over the course of their career, and particularly for periods of foreign training (table 5). The foreign training variable is especially relevant as a measure of investment in expertise, since foreign training is not required (unlike certain types of domestic training courses) and officers would need to expend greater effort in order to find training opportunities outside the country, as well as to arrange funding and the necessary leave from their duties. This provides support for hypothesis 4 that these officers are more willing to invest in developing a reputation for expertise. These regressions are robust to excluding the cohorts prior to 1979 , to employing a tobit model instead of a linear one, and to the inclusion of state fixed effects as a way to control for any differences in incentives arising from which states the officers are initially assigned to (results available on request).

Are there career rewards to such investments? We find that officers of higher initial ability are significantly more likely to be empaneled about twenty years into their careersthat is, recommended for senior positions in the central government (table 6, columns 1 and 2). This strongly suggests that their career investments have resulted in senior 
Table 6.-Bureaucrats' Career Progression: The Role of Skill and (CASte) Loyalty

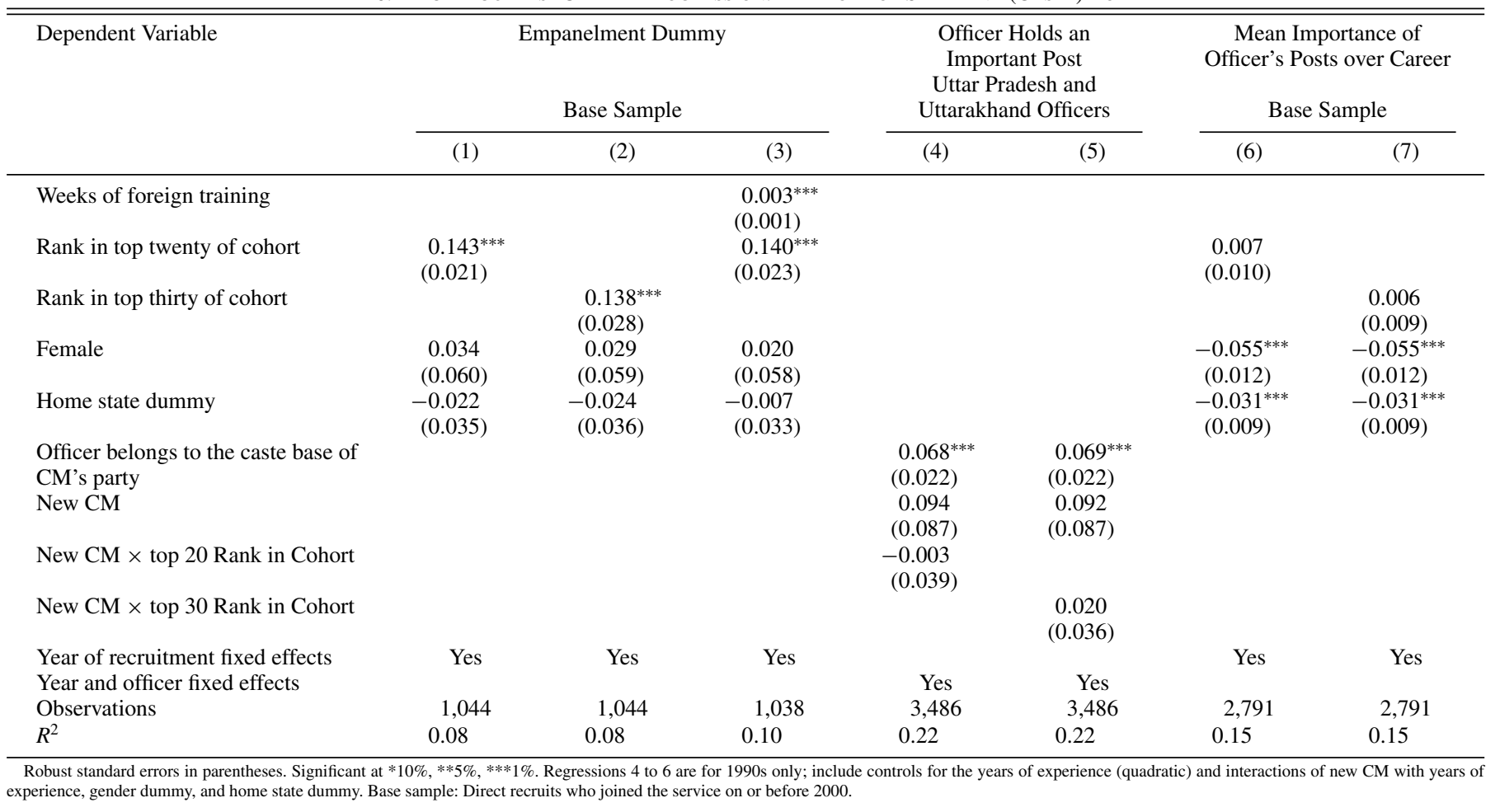

bureaucrats' perceptions of them as competent officers. Central government positions are considered prestigious, and only empaneled officers are eligible for these important posts. Investing in foreign training also significantly increases the probability of getting empaneled, but the impact of initial ability remains strong (table 6 , column 3 ), suggesting that foreign training is only a partial measure of the officer's investment in expertise.

Our model suggests another path to obtaining important positions: developing loyalty to specific politicians. We provide empirical support for the existence of such a loyalty track. As described in section IVC, we computed a measure of whether the officer belongs to the same caste as that of the chief minister's party base, on the assumption that it is easier to develop loyalty links if the politician and the bureaucrat share the same caste identity. We check whether this helps their career concerns by running the following regression:

$$
\begin{aligned}
\text { OfficerinImportantPost }_{i j t}= & a_{i}+b_{t}+\text { hOfficerSameCaste } \\
& +X_{i j t}^{\prime} d+u_{i j t},
\end{aligned}
$$

where OfficerinImportantPost $t_{i j t}$ is a dummy variable for whether officer $i$ of state $j$ holds an important post in year $t, a_{i}$ is a fixed effect for the officer, $b_{t}$ is a fixed effect for the year, OfficerSame Caste ijt $_{\text {is }}$ a dummy that equals 1 if the officer belongs to the caste base of the current chief minister's party, and $X_{i j t}$ is a vector of controls for other time-varying officer and state characteristics. Our theory predicts that the coefficient on OfficerSameCaste should be positive.

We find strong support for this hypothesis: being of the same caste as the chief minister's party base significantly increases an officer's probability of being in an important post by nearly 7 percentage points (table 6 , columns 4 and 5 ). We should note that since this regression is run with officer fixed effects, it compares the same officer at different points of time: when his or her "preferred" chief minister is in power and is not. This is the first empirical analysis of the role of caste in the public sector that we are aware of. ${ }^{29}$

Having provided some evidence that officers have two potentially viable paths to obtaining better career positions, we investigate whether the expertise track yields better career success overall. The answer is no: the average importance of the posts held by an officer over the course of his or her career does not vary significantly with the initial ranking (table 6, columns 6 and 7). This is very much in keeping with our framework, which emphasizes that officers have alternative routes to career success; investment in expertise is not the only one. 30

\section{District Level Transfers and Outcomes}

\section{A. Extending Our Framework: The Role of Local Politicians}

We introduce a subordinate (district-level) politician as a middleman $M$ between the politician and the bureaucrat at the district level. These subordinate politicians belong to one of the two parties, $j \in\{0,1\}$. We assume that subordinates

${ }^{29}$ See Munshi and Rozenzweig (2006) for an empirical analysis of the influence of caste networks on education investments and labor market outcomes in the private sector.

30 The results in columns 1, 2, 3, 6, and 7 are all robust to the inclusion of state fixed effects to control for any effects of being assigned to a specific state. Results available on request. 
from the same party are motivated to act in the interests of the politician and his or her constituents: $s_{M}=1$ if the politician and the subordinate share the same ideology, and $s_{M}=0$ otherwise.

As described in section IIA, we consider district officer positions important posts in our framework. We showed that a politician of type 0 will assign only type $L_{0}$ and type $H$ bureaucrats to these posts; when this person comes into office, he or she would thus thus want to reassign type $L_{1}$ officers in district posts to unimportant ones. However, this can change with the presence of subordinate politicians, depending on whether the subordinate politician and the bureaucrat are complements or substitutes in determining the politician's control over output at the district level. Of course, if local politicians have no effect on a politician's control over bureaucrats, their presence should not affect transfers in any way.

If subordinate politicians and bureaucrats are complements (say, $s^{\text {dist }}=\min \left\{s_{M}, s_{b}\right\}$ ), a newly elected politician will assign all officers loyal to him or her in districts where the local politician is from his or her own party, so we expect to see more bureaucrat transfers in districts where the local politician belongs to the same party as the chief minister. If subordinate politicians and bureaucrats are substitutes (say, $\left.s^{\text {dist }}=\max \left\{s_{M}, s_{b}\right\}\right)$, either a loyal district politician or a loyal bureaucrat is enough to ensure that the politician's interests in the district are well served. This predicts more bureaucrat transfers in districts where the local politicians are not from the same party as the chief minister.

Our discussion above suggests the following hypotheses, which we take to the data:

Hypothesis 5: Following political change, district officer transfer patterns will depend on the proportion of local politicians who belong to the new chief minister's party.

Hypothesis 6: If there is a change in the politician (chief minister) without a change in the party in power, there is no effect of local politicians from the CM's party on transfer patterns.

Although the results of our district-level analysis are interesting in their own right, they also help to rule out some alternative hypotheses about why political change may trigger an increase in bureaucrat transfers, not all of which may be associated with greater inefficiency as portrayed in our framework. For instance, it is not uncommon for a new boss to bring in his or her own team of subordinates for key positions simply because there is an efficient personal match between them, which enhances productivity. However, transfers based on such efficiency of the personal match between the new $\mathrm{CM}$ and the officers should not depend on the presence or absence of local politicians and should happen even if the party in power does not change.

Another alternative hypothesis is that officer transfers are done for purposes of experimentation, to reveal efficient matches between officers and posts. There is no a priori reason to explain why such experimentation should be valuable only when there is a change in the political party, and the value of such information revelation should not depend on the presence or absence of subordinate politicians from the chief minister's party. To summarize, any effect of the party affiliation of subordinate politicians on bureaucrat transfers highlights the role of political control as a motivation for transfers and rules out these alternative, efficiency-driven motivations.

What do our hypotheses here imply for district-level public good outcomes? If, in fact, local politicians and local bureaucrats are good substitutes, it follows that bureaucrat transfers are endogenous to district conditions (political and otherwise). Hence, outcomes need not be systematically different across districts with and without bureaucrat transfers. We test this specific implication of our framework in section VIC.

\section{B. District-Level Bureaucrat Transfers}

We use our data set of district officer transfers to test these predictions, by running the following regression:

$$
\begin{aligned}
\text { Transfer }_{d j t}= & a_{d}+b_{t}+c N e w C M_{j t}+f N e w C M_{j t} \\
& \times \text { DistrictChar }{ }_{d j t}+X_{j t}^{\prime} d+u_{d j t},
\end{aligned}
$$

where Transfer $_{d j t}$ is a dummy variable for whether the district officer of district $d$ of state $j$ was transferred in year $t, a_{d}$ is a fixed effect for the district, $b_{t}$ is a fixed effect for the year, $N e w C M_{j t}$ is a dummy indicating whether a new chief minister came to power in state $j$ in year $t$, DistrictChar ${ }_{d j t}$ represent different district characteristics (in particular, the fraction of local politicians who belong to the same party as the $\mathrm{CM}$ ), and $X_{i j t}$ is a vector of controls for other time-varying state characteristics (state and national elections). For this analysis, we aggregate electoral outcomes to the administrative district level. State electoral districts are usually subsets of administrative districts, with one administrative district containing on average ten electoral districts. ${ }^{31}$

We first document that district officers are indeed significantly likely to be reassigned when a new chief minister takes office (table 7, column 1). The probability of reassignment depends strongly on the presence or absence of local politicians from the CM's party (column 2), consistent with hypothesis 5 . If none of the politicians in a district belongs to the CM's party, then the probability that the bureaucrat is transferred rises by 13.8 percentage points when a new CM comes into office. In contrast, if all the local politicians are from the CM's party, this probability rises by only 3.7 percentage points $(0.138-0.101)$, which is not significantly different from 0 . This strongly favors the interpretation that

${ }^{31}$ All variables are further aggregated to the 1988 administrative district boundaries to account for splits in districts over time. This makes our transfer dummy to lie between 0 and 1 in a few cases; we verify that our results are robust to recoding all transfer probabilities greater than 0.5 as 1 and those less than 0.5 as 0 . 
Table 7.-Do Local Politicians Influence Bureaucrat Transfers? Dependent Variable $=1$ If the District Gets a New District Officer in That Year

\begin{tabular}{|c|c|c|c|c|}
\hline & (1) & $\begin{array}{c}\text { Presence of Local } \\
\text { Politicians } \\
\text { (2) }\end{array}$ & $\begin{array}{c}\text { Local Politicians }+ \\
\text { Party Change } \\
\text { (3) }\end{array}$ & $\begin{array}{c}\text { Political } \\
\text { Turnover } \\
\text { (4) }\end{array}$ \\
\hline New CM dummy & $\begin{array}{l}0.084^{* *} \\
(0.039)\end{array}$ & $\begin{array}{l}0.138^{* * *} \\
(0.034)\end{array}$ & & $\begin{array}{r}0.079^{*} \\
(0.045)\end{array}$ \\
\hline New CM $\times \%$ Local Politicians from CM's party & & $\begin{array}{c}-0.101^{* *} \\
(0.044)\end{array}$ & & \\
\hline New CM, new party & & & $\begin{array}{l}0.232^{* * *} \\
(0.042)\end{array}$ & \\
\hline New CM, no new party & & & $\begin{array}{c}0.049 \\
(0.043)\end{array}$ & \\
\hline New CM, new party $\times \%$ local politicians from CM's party & & & $\begin{array}{c}-0.157^{* *} \\
(0.067)\end{array}$ & \\
\hline New CM, no new party $\times \%$ local politicians from CM's party & & & $\begin{array}{c}0.007 \\
(0.096)\end{array}$ & \\
\hline$\%$ local politicians from CM's party & & $\begin{array}{c}0.033 \\
(0.036)\end{array}$ & $\begin{array}{c}0.035 \\
(0.035)\end{array}$ & \\
\hline New $\mathrm{CM} \times$ political turnover & & & & $\begin{array}{c}0.040 \\
(0.108)\end{array}$ \\
\hline Political turnover & & & & $\begin{array}{r}-0.048 \\
(0.103)\end{array}$ \\
\hline Year fixed effects & Yes & Yes & Yes & Yes \\
\hline District fixed effects & Yes & Yes & Yes & Yes \\
\hline Control for state and general elections & Yes & Yes & Yes & Yes \\
\hline Observations & 6,679 & 6,679 & 6,679 & 6,679 \\
\hline Number of districts & 356 & 356 & 356 & 356 \\
\hline$R^{2}$ & 0.07 & 0.07 & 0.07 & 0.07 \\
\hline
\end{tabular}

local-level politicians and local bureaucrats are viewed as substitutes by the chief minister.

We also find strong support for hypothesis 6: if there is a change in the chief minister without a change in the party in power, there are no significant reassignments of district bureaucrats (table 7 , column 3 ). Finally, we verify that the effects we document are not simply a function of political turnover or the extent of anti-incumbent voting (column 4). ${ }^{32}$

\section{Are District Outcomes Affected by Bureaucrat Transfers?}

As noted at the end of section VIA, transfers of district bureaucrats are endogenous to political considerations at the local level. The effect of bureaucrat transfers on district outcomes is therefore not well identified. Here, we examine two specific measures of district-level policy implementation outcomes: immunization coverage in the year 2001 and the completion status of road projects in 2007. Another major caveat with using these outcomes is that these are only a subset of the district administrator's purview. To get a more comprehensive picture of the effect on district outcomes, we use an overall measure of well-being: poverty reduction over a twelve-year period (1987-1999), based on district-level poverty estimates from Topalova (2005).

In immunization coverage and road completion, we find no significant differences in outcomes in areas with a higher frequency of politician-induced transfers (table 8, columns

\footnotetext{
32 See Linden (2003) for details on the increasing incumbency disadvantage in Indian politics.
}

1-3). ${ }^{33}$ In contrast, with the comprehensive measure of longterm poverty reduction (1987-1999), we observe somewhat greater success in districts with lower politically induced transfers (column 4). Poverty rates declined by 0.9 percentage points less in districts that had a 10 percentage point higher probability of politically induced transfer. This is similar to the effect for poverty reduction over a shorter period, 1993 to 1999, though the latter is not statistically significant (column 5 ). These results suggest that the cost of political transfers in terms of longer-term outcomes can be quite high. It is possible, of course, that the observed associations are driven by variables that affect both the extent of political transfers and the rate of poverty reduction. Our results should therefore be treated as suggestive rather than conclusive.

\section{Conclusion}

In this paper, we have opened up the black box of government by providing one of the first microeconomic analyses of the the interaction between politicians and bureaucrats, using unique data from the Indian Administrative Service (IAS). We find significant political influence on the bureaucracy, despite the constitutional insulation provided to them against political pressures. The patterns of bureaucrat transfers across posts are consistent with the predictions of our model and indicate the presence of two types of inefficiencies. One results from the fact that not all important posts are given to the most competent bureaucrats, and the second

\footnotetext{
${ }^{33}$ Here we define politician-induced transfer as one that happens to coincide with a change in the identity of the chief minister.
} 
TABLE 8.-Bureaucrat Transfers AND District OUTCOMES

\begin{tabular}{|c|c|c|c|c|c|}
\hline & \multirow{2}{*}{$\begin{array}{c}\text { Proportion of } \\
\text { Children } \\
\text { Completely } \\
\text { Immunized, 2001 } \\
\text { (1) }\end{array}$} & \multicolumn{2}{|c|}{$\begin{array}{l}\text { Completion of Road } \\
\text { Projects } 2007\end{array}$} & \multirow{2}{*}{$\begin{array}{c}\text { Change in } \\
\text { Poverty, 1987-1999 } \\
\text { (4) }\end{array}$} & \multirow{2}{*}{$\begin{array}{c}\text { Change in } \\
\text { Poverty, 1993-1999 } \\
\text { (5) }\end{array}$} \\
\hline & & $\begin{array}{l}\text { Sanctioned in } \\
2000 \\
(2)\end{array}$ & $\begin{array}{c}\text { Sanctioned } \\
\text { in } 2003 \\
(3)\end{array}$ & & \\
\hline Mean political transfers in last five years & $\begin{array}{l}-0.013 \\
(0.067)\end{array}$ & $\begin{array}{c}0.131 \\
(0.188)\end{array}$ & $\begin{array}{c}0.181 \\
(0.204)\end{array}$ & & $\begin{array}{c}0.085 \\
(0.049)\end{array}$ \\
\hline Mean other transfers in last five years & $\begin{array}{r}-0.037 \\
(0.072)\end{array}$ & $\begin{array}{c}0.055 \\
(0.136)\end{array}$ & $\begin{array}{r}-0.011 \\
(0.163)\end{array}$ & & $\begin{array}{c}0.045 \\
(0.027)\end{array}$ \\
\hline Mean political transfers in last ten years & & & & $\begin{array}{c}0.087^{*} \\
(0.049)\end{array}$ & \\
\hline Mean other transfers in last ten years & & & & $\begin{array}{c}0.032 \\
(0.040)\end{array}$ & \\
\hline Initial poverty level & & & & $\begin{array}{l}-0.787^{* * *} \\
(0.055)\end{array}$ & $\begin{array}{l}-0.764^{* * *} \\
(0.042)\end{array}$ \\
\hline State FE & Yes & Yes & Yes & Yes & Yes \\
\hline Mean of dependent variable & 0.58 & 0.71 & 0.34 & -0.13 & -0.07 \\
\hline Observations & 363 & 330 & 328 & 350 & 350 \\
\hline$R^{2}$ & 0.70 & 0.54 & 0.28 & 0.69 & 0.65 \\
\hline
\end{tabular}

Robust standard errors in parentheses, clustered at state level. Significant at $* 10 \%, * * 5 \%, * * * 1 \%$. "Completion of road projects 2007 " is a dummy that equals 1 if the road projects sanctioned in a given year were completed by June 2007. "Change in poverty" is the change in the head count ratio.

arises endogenously due to the career concerns of junior bureaucrats: given that competence is not the only consideration for obtaining important positions, junior officers underinvest in developing competence.

What are the implications of our analysis for efficient governance? Our framework suggests that instituting limits on the politician's power to frequently transfer bureaucrats, such as those in a proposed public services bill in India, will reduce the politician's ability to appoint loyal bureaucrats to important positions. This in turn will favorably affect junior officers' incentives to invest in expertise. Similarly, an increase in the politician's transactions costs of reassignment (for instance, through a review process requiring the politician to justify his or her choice of specific bureaucrats) may limit the likelihood of less competent bureaucrats obtaining important posts. Our analysis is also relevant for multilateral agencies that channel funds for public projects through the existing bureaucratic machinery of individual countries. An increase in the funds channeled through bureaucracies may increase the value of officer loyalty to politicians, with adverse long-term consequences for bureaucratic competence. Measures to curtail opportunities for such rent seeking, perhaps by limiting the role of the state in such projects, could be one way to maintain incentives for bureaucratic efficiency.

\section{REFERENCES}

Alesina, Alberto, and Guido Tabellini, "Bureaucrats and Politicians? Part I: A Single Policy Task," American Economic Review 97 (2007), $169-179$.

Banerjee, Abhijit V., and Rohini Pande, "Parochial Politics: Ethnic Preferences and Politician Corruption," working paper (2007).

Bardhan, Pranab, and Dilip Mookherjee, "Decentralization and Accountability in Infrastructure Delivery in Developing Countries," Economic Journal 116 (2006), 101-127.

Bertrand, Marianne, Esther Duflo, and Sendhil Mullainathan, "How Much Should We Trust Differences-in-Differences Estimates?" Quarterly Journal of Economics 119 (2004), 249-276.

Besley, Timothy, and Stephen Coate, "Elected versus Appointed Regulators," Journal of the European Economics Association 1 (2003), 1176-1206.
Besley, Timothy, and Maitreesh Ghatak, "Competition and Incentives with Motivated Agents," American Economic Review 95 (2005) 616-636.

Besley, Timothy, Rohini Pande, and Vijayendra Rao, "Just Rewards? Local Politics and Public Resource Allocation in South India," working paper (2007).

Besley, Timothy, and Abigail Payne, "Judicial Accountability and Economic Policy Outcomes: Evidence from Employment Discrimination Charges," working paper (2003).

Calvert, R. McCubbins, and Barry Weingast, "A Theory of Political Control and Agency Discretion," American Journal of Political Science 33 (1989), 588-611.

Chandra, Kanchan, Why Ethnic Parties Succeed: Patronage and Ethnic Headcounts in India (Cambridge: Cambridge University Press, 2004).

Das, S. K., Public Office, Private Interest: Bureaucracy and Corruption in India (New Delhi: Oxford University Press, 2001).

de Zwart, Frank, The Bureaucratic Merry-Go-Round: Manipulating the Transfer of Indian Civil Servants (Amsterdam: Amsterdam University Press, 1994).

Dewatripont, Mathias, Ian Jewitt, and Jean Tirole, "The Economics of Career Concerns, Part II: Application to Missions and Accountability of Government Agencies," Review of Economic Studies 66 (1999), 199-217.

di Tella, Rafael, and Ray Fisman, "Are Politicians Really Paid like Bureaucrats?" Journal of Law and Economics 47 (2004), 477-514.

Dixit, Avinash, "Democracy, Autocracy, and Bureaucracy," Journal of Globalization and Development 1:1 (2010), article 1.

Epstein, David, and Sharyn O'Halloran, Delegating Powers: A Transactions Cost Approach to Policymaking under Separate Powers (Cambridge: Cambridge University Press, 1999).

Evans, Peter, Embedded Autonomy: States and Industrial Transformation (Princeton, NJ: Princeton University Press, 1995).

Ferraz, Claudio, and Frederico Finan, "Motivating Politicians: The Impacts of Monetary Incentives on Quality and Performance," working paper (2008).

Gilmour, David, The Ruling Caste: Imperial Lives in the Victorian Raj (New York: Farrar, Straus and Giroux, 2005).

Holmstrom, Bengt, and Paul Milgrom, "Multi-Task Principal-Agent Problems: Incentive Contracts, Asset Ownership and Job Design," Journal of Law, Economics and Organization 7 (1991), 24-52.

Khemani, Stuti, "Partisan Politics and Intergovernmental Transfers in India," World Bank policy research working paper no. 3016 (2003).

Kingston, Christopher, "Corruption and Social Structure: Theory, and Evidence from India,” BREAD working paper no. 075 (2004).

Lim, Claire S. H., "Turnover and Accountability of Appointed and Elected Judges," working paper (2008).

Linden, Leigh, "Are Incumbents Always Advantaged? The Preference for Non-Incumbents in India," working paper (2003). 
Maskin, Eric, and Jean Tirole, "The Politician and the Judge: Accountability in Government," American Economic Review 94 (2004), 1034-1054.

Mueller, Hannes, "Patronage, Meritocracy and Political Competition: Exploring an Empirical Puzzle," working paper (2007).

Munshi, Kaivan, and Mark Rozenzweig, "Traditional Institutions Meet the Modern World: Caste, Gender, and Schooling Choice in a Globalizing Economy," American Economic Review 96 (2006), $1225-1252$.

Park, No-Wook, and Rohini Somanathan, "Patronage in Public Administration: Presidential Connections, Position Assignments and the Performance of Korean Public Prosecutors, 1992-2000," working paper (2004).

Potter, David C., India's Political Administrators: From ICS to the IAS (New Delhi: Oxford University Press, 1996).

Prendergast, Canice, "The Motivation and Bias of Bureaucrats," American Economic Review 97 (2007), 180-196.

Ramseyer, Mark, and Eric Rasmusen, "Why Are Japanese Judges So Conservative in Politically Charged Cases?" American Political Science Review 95 (2001), 331-344.
Rauch, James, "Bureaucracy, Infrastructure and Economic Growth: Evidence from U.S. Cities during the Progressive Era," American Economic Review 85 (1995), 968-979.

Rauch, James, and Peter Evans, "Bureaucratic Structure and Bureaucratic Performance in Less Developed Countries," Journal of Public Economics 75 (2000), 49-71.

Smart, Michael, and Daniel Sturm, "Term Limits and Electoral Accountability," CEPR discussion paper no. 4272 (2008).

Swarup, Hem Lata, and Niroj Sinha, "Women in Public Administration in India," in Jane H. Bayes (Ed.), Women in Public Administration: International Perspectives (Birmingham, NY: Haworth Press, 1991).

Topalova, Petia, "Trade Liberalization, Poverty and Inequality: Evidence from Indian Districts," NBER working paper no. 11614 (2005).

Wade, Robert, "The System of Administrative and Political Corruption: Canal Irrigation in South India," Journal of Development Studies 18 (1982), 287-328.

Weingast, Barry, and Mark J. Moran, "Bureaucratic Discretion or Congressional Control? Regulatory Policymaking at the FTC," Journal of Political Economy 91 (1983), 765-800. 